\title{
Heat Shock Protein 105 kDa
}

National Cancer Institute

\section{Source}

National Cancer Institute. Heat Shock Protein 105 kDa. NCI Thesaurus. Code C116976.

Heat shock protein $105 \mathrm{kDa}$ (858 aa, $\sim 97 \mathrm{kDa}$ ) is encoded by the human HSPH1 gene.

This protein plays a role in the cellular stress response to unfolded proteins. 